\title{
FULL LENGTH RESEARCH ARTICLE \\ DETERMINATION OF SELECTED METALS IN COAL SAMPLES FROM LAFIA-OBI AND CHIKILA
}

\author{
*JAURO, A.; CHIGOZIE, A. A. \& NASIRUDEEN, M. B. \\ Chemistry Programme \\ Abubakar Tafawa Balewa University \\ PMB 0248, Bauchi Nigeria \\ *(Corresponding author) \\ alijauro@daad-alumni.de
}

\begin{abstract}
The concentration of iron, aluminum, chromium, magnesium cadmium, potassium, lead and copper in Lafia-Obi and Chikila coal samples were determined using atomic absorption spectroscopy (AAS). All the samples have comparable chromium and copper contents, while iron, aluminum, magnesium and potassium content vary to some extent. Metals concentrations in both Lafia-Obi and Chikila coal samples are within the limits allowed by the Federal Environmental Protection Agency (FEPA) except in Chikila (UBCJ-1) and Lafia-Obi (MBJJ-6) coal samples where iron was observed to be higher than the stipulated $20 \mathrm{ppm}$. These show that the disposal of ash generated from the combustion of these coals may not pose a potential threat to environment.
\end{abstract}

Key words: Coal ash, environment, heavy metals, pollution, proximate analysis, Atomic Absorption Spectroscopy

\section{INTRODUCTION}

Coal is one of the most impure fuels. The impurities range from trace quantities of aluminum and thorium, to larger quantities of aluminum and iron. The metallic elements in coal can have profound environmental, economic, technological and human health impacts (Renton 1982; Kolker et al. 2001). Therefore, knowledge of their concentration is required when evaluating coals for combustion and conversion and also to assess potential negative environmental and health impacts resulting from coal use.

Recent studies (Obaje 1997; Nwadinigwe 2002) have shown that there are more deposits of coal in Nigeria than have previously been documented. Presently, the only exploited deposits are those of Okaba, Onyeama, Okpara and Okwukpa, which are mainly used for combustion purposes (NCC 1997). Despite the reported occurrences of other coal deposits in Chikila, Lamza, Doho, Kumo, Lafia-Obi, and $\mathrm{G} /$ maiganga, information regarding their investigation is rare (Obaje 1997; Jauro et al. 2008).

The technical problems encountered in combustion are primarily concerned with the ash-fusion characteristics and viscosity of the molten ash (Renton 1982). The behavior of a coal's ash residue at high temperature is a critical factor in selecting coals for steam power generation because most furnaces are designed to remove ash as powdery residue. Coal which has ash that form clinker is usually unsatisfactory in furnaces because it leads to the fouling of heat exchanger pipes (USGS 2008) and the furnace requires cleaning or a special furnace design. The elements responsible for most of these problems are the alkali elements, sodium and potassium, and the alkali earth, calcium and magnesium along with silicon, aluminum, iron, sulfur, chlorine and titanium (Renton 1982; Perry et al. 1984). Trace elements in coal are emitted into flue gas, fly ash or bottom ash of combustion plants. In the flue gas, trace elements are released as gaseous or particle bound forms in coal combustion processes. In a flue gas stream, trace elements are fixed in ash particles and in byproducts such as gypsum and sludge if wet flue gas desulphurization unit is equipped. Coal ash is composed primarily of oxides of silicon, aluminum, iron, calcium, magnesium, titanium, sodium, potassium, arsenic, mercury and sulfur plus small quantities of uranium and thorium. Disposal of coal ash is becoming a major issue because of its potential to contaminate surface and groundwater with arsenic, boron etc (Mudel et al. 1996; Kim \& Kazonich 1999).

This paper investigates the presence and concentration of cadmium, chromium, lead, copper, potassium, aluminum, iron, magnesium in Lafia-Obi and Chikila coals. The metal concentration levels would serve as an index for assessing the possible environmental problems the coals may pose when put into use.

\section{MATERIALS AND METHODS}

The coal samples from both Lafia-Obi and Chikila were obtained from the National Metallurgical Research and Development Center, Jos Nigeria. The samples were reduced to smaller sizes by breaking with a hand-held hammer, followed by pulverizing in a rotary mill. The powdered samples were passed through a 210 micron sieve. The gross sample was then divided using a sample divider in stages to a small analysis sample representative of the original gross sample. $5 \mathrm{~g}$ of the sample was weighed into a platinum crucible and ignited in a muffle furnace at $85^{\circ} \mathrm{C}$. The sample was removed and allowed to cool in a desiccator. $0.1 \mathrm{~g}$ of the ash sample was weighed into a clean dry beaker and moistened with a little distilled water. The dish was placed on a hot plate and its content digested with $8 \mathrm{~cm}^{3}$ of nitric acid $\left(\mathrm{HNO}_{3}\right)$ and perchloric acid $\left(\mathrm{HClO}_{4}\right)(15: 15)$ and left to stand overnight after which it was evaporated to dryness and allowed to cool, without baking. Grained particles remained so $2 \mathrm{~cm}^{3}$ of perchloric acid was added and evaporated to dryness. $10 \mathrm{~cm}^{3}$ of $2 \mathrm{M}$ hydrochloric acid $(\mathrm{HCl})$ was added to prevent boiling. The solution was cooled and filtered into a $100 \mathrm{~cm}^{3}$ volumetric flask and diluted to mark with distilled water.

Standard solutions of aluminum, iron, chromium, cadmium, potassium, lead and copper were prepared. Calibration standards were prepared 
from the stock solutions. The absorbance of the standards and coal samples were measured using Winelight Unicam 969 Atomic Absorption Spectrophotometer. The corresponding absorbance response for each standard was plotted against its concentration for calibration. Sample response was compared directly with the calibration curve (ASTM 1992).

\section{RESULTS}

Proximate Analysis: Table 1 shows the mean percentage vitrinite reflectance $\left(\% \mathrm{R}_{\mathrm{m}}\right)$, proximate analysis and sulfur contents of the coal samples.

Concentration of Metals: The concentration of some trace and major metallic elements in the coal samples are given in Table 2.

TABLE 1: THE MEAN VITINITE REFLECTANCE, PROXIMATE ANALYSIS AND SULPHUR CONTENT OF LAFIA-OBI AND CHIKILA COAL SAMPLES

\begin{tabular}{lllllll}
\hline $\begin{array}{l}\text { Coal } \\
\text { samples }\end{array}$ & $(\% \mathrm{Rm})$ & $\begin{array}{l}\text { Moisture } \\
(\mathbf{w t} \%)\end{array}$ & Vm (\%db) & Ash (\%db) & FC (\%) & $\begin{array}{l}\text { Sulphur } \\
(\%)\end{array}$ \\
\hline MBJJ 2 & 0.992 & 0.84 & 30.45 & 16.57 & 50.88 & 2.1 \\
MBJJ 3 & 0.962 & 0.83 & 31.93 & 17.59 & 48.43 & 2.05 \\
MBJJ 1 & 0.698 & 4.28 & 41.79 & 10.02 & 47.25 & 0.94 \\
UBCJ 7 & 0.662 & 3.98 & 38.94 & 13.21 & 45.54 & 1.01 \\
\hline
\end{tabular}

$\mathrm{Rm}=$ Mean percentage vitrinite reflectance; $\mathrm{VM}=$ Volatile Matter; $\mathrm{Fc}=$ Fixed carbon; $\mathrm{db}=\mathrm{dry}$ basis

TABLE 2. CONCENTRATION OF SOME METALS IN LAFIA-OBI AND CHILILA COAL SAMPLES

\begin{tabular}{lllllllll}
\hline $\begin{array}{l}\text { Coal } \\
\text { samples }\end{array}$ & $\begin{array}{l}\text { Fe } \\
(\mathbf{p p m})\end{array}$ & $\begin{array}{l}\mathrm{A} \\
(\mathbf{p p m})\end{array}$ & $\begin{array}{l}\mathrm{Cr} \\
(\mathrm{ppm})\end{array}$ & $\begin{array}{l}\mathrm{Mg} \\
(\mathbf{p p m})\end{array}$ & $\begin{array}{l}\text { Cd } \\
(\mathbf{p p m})\end{array}$ & $\begin{array}{l}\mathrm{K} \\
(\mathbf{p p m})\end{array}$ & $\begin{array}{l}\mathrm{Pb} \\
(\mathbf{p p m})\end{array}$ & $\begin{array}{l}\text { Cu } \\
(\mathrm{ppm})\end{array}$ \\
\hline MBJJ 2 & 9.38 & 69.604 & 0.889 & 2.598 & $\mathrm{ND}$ & 1.066 & $\mathrm{ND}$ & 0.182 \\
MBJJ 6 & 49.558 & 40.096 & 0.998 & 2.526 & $\mathrm{ND}$ & 1.289 & $\mathrm{ND}$ & 0.239 \\
UBCJ 1 & 21.195 & $\mathrm{ND}$ & 0.828 & 20.225 & 0.008 & 2.481 & $\mathrm{ND}$ & 0.222 \\
UBCJ 3 & 13.896 & 25.326 & 0.907 & 9.371 & $\mathrm{ND}$ & 0.659 & $\mathrm{ND}$ & 0.197 \\
FEPA Limit & 20 & & $<1$ & 200 & $<1$ & & $<1$ & $<1$ \\
\hline
\end{tabular}

$\mathrm{ND}=$ Not done; FEPA=Federal Environmental Protection Agency

\section{DISCUSSION}

Based on the vitrinite reflectance values (\% $\mathrm{Rm})$, maturity of Lafia-Obi samples is higher than that of Chikila. Reflectance values of $\sim 0.70$ observed in Chikila samples suggest that the coals belong to high volatile bituminous coal B rank, while reflectance values of $\sim 1.00 \%$ in Lafia-Obi belongs to high volatile bituminous coal A rank (ASTM 1992). Volatile matter content of Lafia-Obi that is lower than that of Chikila (Tab. 2) could be due to maturity influence because volatile matter is known to decrease with increase in rank (Price et al. 1997; Akpabio 1998).Volatile matter apart from its use in coal ranking is one of the most important parameters used in determining coal's applications (Peng 2002). Considering the coals' moisture contents, Lafia-Obi coal is higher in quality, because of its low moisture. High moisture leads to a decrease plant capacity and an increase in its operating costs. This is by affecting the calorific value and the concentration of other constituents (IEA/OECD 2002). High carbon content is essential for applications such as coke making because they form the actual coke (Diez et al. 2002). The carbon contents of both samples are appreciably good.

The data show that all the elements investigated in these coals have mean contents lower than the Chinese Permian coals (Shifeng et al. 2005). In comparison with the earth crust (Taylor 1964); all the studied elements are much lower in the Nigerian coals. Lafia-Obi is richer than Chikila in iron and aluminum, while Chikila is richer than Lafia-Obi in magnesium and potassium. There is no significant difference in the concentration of chromium (0.828-0.998\%), cadmium $(0.008 \%)$ and copper $(0.182-0.222 \%)$ of the two coals (Tab. 2). The observed variation in the concentration of the individual metals in the various samples may be due to minerals compositional difference arising at the epigenetic phase or syngenetic phase of the coal formation (Renton 1982). Disposal and/or any use of coal ash are becoming a major issue because of its potential to contaminate surface and ground water with metals. The concentrations of metals in both LafiaObi and Chikila coal samples are within the limits allowed by the Federal Environmental Protection Agency (FEPA 1991) with few exceptions (Tab. 2).

Concentration of iron in a sample from Chikila (UBCJ-1; 21.195 ppm) and a sample from Lafia-Obi (UBCJ-6; 49.558 ppm) are above the FEPA stipulated limit of $20 \mathrm{ppm}$, other samples have concentration lower than that (FEPA 1991). High iron concentration in coal is undesirable because chronic inhalation of iron oxide dust or fume may result in development of benign pneumoconiosis called siderosis. It also enhances the risk of lung cancer (Lenntech 2008). Magnesium concentrations in all samples are well below 10 ppm, except in UBCJ1 , where concentration of $20.225 \mathrm{ppm}$ was recorded. Therefore concentrations of magnesium in both Lafia-Obi and Chikila samples are far below the 200 ppm stipulated by FEPA.

The concentration of copper in both Lafia-Obi and Chikila samples are all lower than 0.2 ppm, far below the allowed 1 ppm limit (FEPA 1991). 
This show that copper in the ash may not pose any threat to the environment. The concentration of chromium in both Lafia-Obi and Chikila coal samples are closely the same with concentrations close to but not up to $1 \mathrm{ppm}$, which is the allowed limit (Tab. 2). Accumulation of lead in human body can lead to a disease called plumbism, while ouchouch is caused by the accumulation of cadmium in the body (Martin \& Coughtrey 1982). The concentration of lead and cadmium in the samples are below detection limit, except in UBCJ-1 where cadmium was detected and was found to be within the FEPA limit.

Vitrinite reflectance measurement and proximate analysis places LafiaObi in the high volatile bituminous coal A rank, while Chikila is in high volatile bituminous coal B rank. Both Lafia-Obi and Chikila coal samples have comparable chromium and copper contents, while iron, aluminum, magnesium and potassium content vary to some extent. The concentrations of metals for both Lafia-Obi and Chikila coal samples are within the limits allowed by the Federal Environmental Protection Agency (FEPA) except in Chikila (UBCJ-1) and Lafia-Obi (MBJJ-6) coal samples where iron was observed to be higher than the stipulated 20 ppm. These show that coal ash emanating from the combustion of both Lafia-Obi and Chikila may not pose a potential environmental threat on disposal.

\section{REFERENCES}

Akpabio, I. O. 1998. Thermal properties of some Nigerian coals. Journal of Pure and Applied Science, 1: 87-92.

American Society for Testing and Materials Annual Book of ASTM Standards 1992. Section 5: Petroleum Products, Lubricants and Fossil Fuels. 5.05: Gaseous Fuels; Coal and Coke.

Federal Environmental Protection Agency (FEPA) Regulations 1991. Abuja: S. I 8 effluent and S. I. 9 pollution abatement in industries and facilities generating wastes.

Jauro, A.; Agho, M. O.; Abayeh, O. J.; Obaje, N. G. \& Abubakar, M. B. 2008. Petrographic studies and coking properties of Lamza, Chikila and Lafia-Obi coals of the Benue trough. Nigerian Journal of Mining and Geology, 44: 11-19.

Kim, A. G. \& Kazonich, G. 1999. International utilization symposium, Centre for applied energy research, University of Kentucky, USA.

Kolker, A.; Finkelman, R. B.; Palmer, C. A.; \& Belkin, H. E. 2001. Arsenic, mercury and other trace metals in coal: Environmental and health implications (Abstract, International Ash Utilization Symposium, Lexington, KY)
Lenntech, 2008. Health effects of iron. Retrieved on $27^{\text {th }}$ May 2008 from http://www.lenntech.com/periodic-chart-elements/Fe-en.htm

Martin, M. H. \& Coughtrey, P. J. 1982. Biological monitoring of heavy metal pollution. Applied Science Publishers, New York.

Mudel, G. M.; Kodikara, J. \& McKinley, T. 1996. Assessing the environmental impact of coal ash disposal. Paper presented at the AIE $7^{\text {th }}$ Australian Coal Science Conference, Churchill, Victoria.

NCC. 1997. Nigerian Coal Corporation Information Manual. $7^{\text {th }}$ OAU/AEC Trade Fair.

Nwadinigwe, C. A. 2002. Nigeria's coal: a much neglected prime resource, Chemistry in Nigeria, 1:2.

Obaje, N. G. 1997. Petrographic evaluation of the coking potential of the Cretaceous Obi/Lafia coal deposits in the Benue trough of Nigeria. Zeitschrift fur Angewandte Geologie, 43:4.

Perry, G. J.; Allandice, D. J. \& Kiss, L. T. 1984. In: Schobert, H. H. 1984 (Ed.). The chemistry of low-rank coals. American Chemical Society, Washington.

Price, J.; Gransden, J. \& Hampel, K. 1997. Microscopy, Chemistry and Rheology tools to determine Coal and Coke Characteristics. $1^{\text {st }}$ McMaster's cokemaking course. McMaster's University Hamilton, Ontario, Canada. 4.1-4.74.

Renton, J. J. 1982. Mineral matters in coal, In: Meyers, R. A. (Ed.). Coal Structure. New York Academy Press.

Shifeng, D.; Deyi, R.; Yuegang, T.; Mei Y. \& Liming, H. 2005. Concentration and distribution of elements in late Permian coals from western Guizhou Province, China. International Journal of Coal Geology, 61: 119-137.

Taylor, S. R. 1964. Abundance of chemical elements in the continental crust: a new table. Geochimica et Cosmomichica Acta, 28:1273.

USGS 2008. Coal-quality information-key to the efficient and environmentally sound use of coal. U.S. Geological Survey Energy Resources Program USGS Fact Sheet FS-171-97. Retrieved 20th May, 2008 from http://energy.usgs.gov/factsheets/coalqual/coalqual.html on $\underline{20-05-08}$ 